\section{Soft skill elements in structured clinical nursing assessment for undergraduate nursing students: A systematic review}

By: Jamaludin, TSS (Jamaludin, Thandar Soe Sumaiyah) ${ }^{[1]}$; Nurumal, MS (Nurumal, Mohd Said) ${ }^{[1]}$; Ahmad, N (Ahmad, Norfadzilah) ${ }^{[1]}$; Muhammad, SAN (Muhammad, Siti Aesah Naznin) ${ }^{[2]}$; Chan, CM (Chan, Chong Mei) $^{[3]^{1}}$

\section{ENFERMERIA CLINICA}

Volume: 31 Pages: S58-S62 Supplement: 2

DOI: $10.1016 /$ j.enfcli.2020.10.019

Published: APR 2021

Document Type: Article

\section{Abstract}

This systematic review aimed to appraise and synthesize the available evidence that examines the soft skill elements in clinical nursing assessment for undergraduate nursing students. This systematic review also is in line with the Preferred Reporting Items for Systematic Reviews and Meta-Analyses (PRISMA) guidelines. Relevant studies were identified based on the inclusion criteria with language filters but were limited to articles published from January 2000 to March 2019. Two reviewers independently conducted the quality assessment, data extraction, and analysis on all included studies. A total of 17 articles were included in this review. Studies showed that without developing adequate soft skill elements in the clinical skill assessment, students are graduating unprepared to be successful in the workplace. There is a need to consider and adopt soft skill elements in clinical skill assessment to improve the quality of nursing graduates and ultimately to create a positive impact on patient outcomes. (C) 2020 Elsevier Espana, S.L.U. All rights reserved.

\section{Keywords}

Author Keywords: Soft skill; Clinical nursing assessment; Clinical nursing practice; Undergraduate nursing student; Under graduate nursing programme

KeyWords Plus: ASSESSMENT-TOOL; COMPETENCE

\section{Author Information}

\section{Reprint Address:}

International Islamic University Malaysia Int Islamic Univ Malaysia, Kulliyyah Nursing, Kuantan Campus, Pahang, Malaysia.

Corresponding Address: Nurumal, MS (corresponding author)

+ Int Islamic Univ Malaysia, Kulliyyah Nursing, Kuantan Campus, Pahang, Malaysia. Addresses:

+ [1] Int Islamic Univ Malaysia, Kulliyyah Nursing, Kuantan Campus, Pahang, Malaysia

+ [2 ] Int Islamic Univ Malaysia, Kulliyyah Med, Kuantan Campus, Pahang, Malaysia

+ [3] Univ Malaya, Fac Med, Dept Nursing Sci, Kuala Lumpur, Malaysia

E-mail Addresses: mohdsaid@iium.edu.my

Funding

\begin{tabular}{|l|l|}
\hline Funding Agency Show details & Grant Number \\
\hline Ministry of Education, Malaysia & RACER19-021-0021 \\
\hline
\end{tabular}

View funding text

Publisher

ELSEVIER ESPANA SLU, AV JOSEP TARRADELLAS, 20-30, 1ERA PLANTA, BARCELONA, CP-08029, SPAIN

Categories / Classification

Research Areas: Nursing

Web of Science Categories: Nursing

\section{See more data fields}

\section{Citation Network}

In Web of Science Core Collection

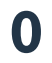

Times Cited

Create Citation Alert

\section{0}

\section{Cited References}

View Related Records

(i) New! You may also like ... ${ }^{\text {BETA }}$

The integrality of children care in the perception of undergraduate nursing student.

REVISTA BRASILEIRA DE ENFERMAGEM (2012)

Commendations, Conversations, and LifeChanging Realizations: Teaching and Practicing Family Nursing. JOURNAL OF FAMILY NURSING (2010)

The Future Of Work: "Soft Skill" For New Generation.

MODERN JOURNAL OF LANGUAGE TEACHING METHODS (2018)

Facilitators and barriers in implementing clinical nursing assessment in mental

health care for older people: A

multimethod approach.

NURSING \& HEALTH SCIENCES (2021)

Views and experiences of mental health nurses working with undergraduate assistants in nursing in an acute mental health setting.

INTERNATIONAL JOURNAL OF MENTAL HEALTH NURSING (2012)

View all suggestions

\section{Use in Web of Science}

Web of Science Usage Count

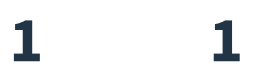

Last 180 Days $\quad$ Since 2013

Learn more

\section{This record is from:}

Web of Science Core Collection

- Emerging Sources Citation Index

\section{Suggest a correction}

If you would like to improve the quality of the data in this record, please suggest a correction. 


\section{Cited References: 20}

1. Nursing students' experiences of assessment by the Swedish National Clinical Final Examination

By: Andersson, Petra Lilja; Ahlner-Elmqvist, Marianne; Johansson, Unn-Britt; et al.

NURSE EDUCATION TODAY Volume: 33 Issue: 5 Pages: 536-540 Published: MAY 2013

2. Title: [not available]

Times Cited: 1

By: [Anonymous].

Checklist for systematic reviews and research syntheses Published: 2017

Internet cited

Publisher: The Joanna Briggs Institute, Adelaide

URL: https://joannabriggs.org/sites/default/files/2019-05/JBI Critical Appraisal-Checklistfor Systematic Reviews2017 0.pdf

3. Student preparedness characteristics important for clinical learning: perspectives of supervisors from medicine,

pharmacy and nursing

By: Banneheke, Hasini; Nadarajah, Vishna Devi; Ramamurthy, Srinivasan; et al.

BMC MEDICAL EDUCATION Volume: 17 Article Number: 130 Published: AUG 82017

4. Nursing students' views of clinical competence assessment.

Times Cited: 21

By: Bradshaw, Carmel; O'Connor, Maureen; Egan, Geraldine; et al.

British journal of nursing (Mark Allen Publishing) Volume: 21 Issue: 15 Pages: 923-7 Published: 2012 Aug 9-Sep 12

5. Implementing objective structured clinical skills evaluation (OSCE) in nurse registration programmes in a centre in reland: A utilisation focused evaluation

By: Brosnan, M; Evans, W; Brosnan, E; et al.

NURSE EDUCATION TODAY Volume: 26 Issue: 2 Pages: 115-122 Published: FEB 2006

6. Preceptors' views of assessing nursing students using a competency based approach.

By: Cassidy, Irene; Butler, Mary Pat; Quillinan, Bernie; et al.

Nurse education in practice Volume: 12 Issue: 6 Pages: 346-51 Published: 2012 -Nov (Epub 2012 May 27)

7. Development and psychometric evaluation of the competency inventory for nursing students: A learning outcome perspective

By: Hsu, Li-Ling; Hsieh, Suh-Ing

NURSE EDUCATION TODAY Volume: 33 Issue: 5 Pages: 492-497 Published: MAY 2013

8. Nursing students' perceptions of clinical supervision: The contributions of preceptors, head preceptors and clinical lecturers

By: Kristofferzon, Marja-Leena; Martensson, Gunilla; Mamhidir, Anna-Greta; et al.

NURSE EDUCATION TODAY Volume: 33 Issue: 10 Pages: 1252-1257 Published: OCT 2013

9. Nursing students' perceptions of soft skills training in Ghana (View record in SciELO Citation Index)

Times Cited: 6

By: Laari, Luke; Dube, Barbara M.

Curationis Volume: 40 Issue: 1 Pages: 1-5 Published: 2017

10. Implementing a clinical competency assessment model that promotes critical reflection and ensures nursing graduates' readiness for professional practice.

By: Levett-Jones, Tracy; Gersbach, Jean; Arthur, Carol; et al.

Nurse education in practice Volume: 11 Issue: 1 Pages: 64-9 Published: 2011 -Jan (Epub 2010 Aug 19)

11. Preferred reporting items for systematic review and meta-analysis protocols (PRISMA-P) 2015 statement

By: Moher, David; Shamseer, Larissa; Clarke, Mike; et al.

Group Author(s): PRISMA-P Grp

REVISTA ESPANOLA DE NUTRICION HUMANA Y DIETETICA Volume: 20 Issue: 2 Pages: 148-160 Published: 2016

12. Model of practical skill performance as an instrument for supervision and formative assessment

Times Cited: 11

By: Nielsen, Carsten; Sommer, Irene; Larsen, Karin; et al.

NURSE EDUCATION IN PRACTICE Volume: 13 Issue: 3 Pages: 176-180 Published: MAY 2013

13. The validity and reliability of methods to assess the competence to practise of pre-registration nursing and midwifery students

By: Norman, IJ; Watson, R; Murrells, T; et al.

INTERNATIONAL JOURNAL OF NURSING STUDIES Volume: 39 Issue: 2 Pages: 133-145 Published: FEB 2002

14. The visibility of QSEN competencies in clinical assessment tools in Swedish nurse education 
15. Balancing the evidence: incorporating the synthesis of qualitative data into systematic reviews

Times Cited: 139

By: Pearson, A.

JBI Rep Volume: 2 Pages: 45-64 Published: 2004

URL: https://doi-org.ezproxy.um.edu.my/10.1111/j.1479-6988.2004.00008.x

16. Generic Skills among Technical Students in Malaysia

Times Cited: 14

By: Rahman, Saemah; Mokhtar, Seri Bunian; Hamzah, Ruhizan Mohd Yasin Mohd Izham Mohd

3RD WORLD CONFERENCE ON EDUCATIONAL SCIENCES - 2011 Book Series: Procedia Social and Behavioral Sciences Volume: 15

Pages: 3713-3717 Published: 2011

17. Development and validation of a Clinical Assessment Tool for Nursing Education (CAT-NE)

Times Cited: 10

By: Skuladottir, Hafdis; Svavars dottir, Margret Hronn

NURSE EDUCATION IN PRACTICE Volume: 20 Pages: 31-38 Published: SEP 2016

18. Evaluating the objective structured long examination record for nurse education.

Times Cited: 3

By: Traynor, Marian; Galanouli, Despina; Rice, Billiejoan; et al.

British journal of nursing (Mark Allen Publishing) Volume: 25 Issue: 12 Pages: 681-7 Published: 2016 -Jun-23

19. Developing an assessment tool for intended learning outcomes in clinical practice for nursing students

By: Ulfvarson, Johanna; Oxelmark, Lena

Times Cited: 14

NURSE EDUCATION TODAY Volume: 32 Issue: 6 Pages: 703-708 Published: AUG 2012

20. Assessment of a low-fidelity human patient simulator for the acquisition of nursing skills

By: Wilson, M; Shepherd, I; Kelly, C; et al.

Times Cited: 33

NURSE EDUCATION TODAY Volume: 25 Issue: 1 Pages: 56-67 Published: JAN 2005

Showing $\mathbf{2 0}$ of $\mathbf{2 0} \quad$ View All in Cited References page 